\title{
Dış Ticaretin Gelişiminde Gümrük Birliği’nin Rolü, Bir Algı Araştırması \\ ****
}

\section{The Role of the Customs Union in The Development of Foreign Trade, A Perception Survey}

\author{
Yrd. Doç. Dr. Hakan TUNÇ
}

Mehmet Akif Ersoy Üniversitesi, Bucak Zeliha Tolunay Uygulamalı Teknoloji ve İşletmecilik Yüksekokulu Uluslararası Ticaret Bölümü, htunc@ mehmetakif.edu.tr

\section{Özet}

Ülkelerin kendi aralarında her türlü gümrük tarifesini kaldırdığı ve diğer ülkelere ortak gümrük tarifesi uyguladıkları iktisadi birleşme türüne, Gümrük Birliği denir. Bu birleşmedeki temel amaç sürdürülebilir bir dış ticaret haddine sahip olmaktır. $\mathrm{Bu}$ çalışmada ilk olarak Türkiye'nin Gümrük birliğine girişinin Türk dış ticaretine etkisi 1997-2016 yılları arası 25 üyeli Avrupa Birliği ile yaptığı ihracat ve ithalat verileri kullanılarak incelenmiş, 1997 yılı ile 2016 yılları arası ihracattaki toplam büyüme \% 188, ithalattaki toplam büyüme ise \% 150 hesaplanmıştır. Ayrıca çalışmanın son bölümünde kişilerin Türkiye'nin Gümrük Birliği'ne girmesinin, Türkiye dış ticaretine etkisi ve Gümrük Birliği'nin gelecekte Türkiye dış ticaretinin nasıl etkileyeceği konularında düşüncelerini almak amacıyla Likert ölçekte bir anket uygulaması yapılmıştır. Yapılan varyans testi sonucunda Kişilerin aldığı eğitim ile gelecekte gümrük birliğinin ihracatı ve ithalatı olumlu etkileyeceği beklentisi arasında istatistiksel olarak anlamlı bir fark bulunamamıştır.

Anahtar Kelimeler: Gümrük Birliği, Dış Ticaret, Algı, Varyans Testi

JEL Sinıflandırma Kodlar: F15, F14, F13, F35

\begin{abstract}
Countries have removed all customs tariffs among themselves and They practice common custom tariffs to other countries, types of economic integration defined Custom Union. The main purpose of this union is to have a sustainable foreign trade line. In this study, first of all, the effect of the entry of Turkey into Customs Union on Turkish foreign trade, examined that used by export and import data with the 25member European Union between 1997-2016, was calculated total growth in exports from 1997 to 2016 as $188 \%$ and the total growth in imports as $150 \%$. Also in the last part of the study to take people's thoughts about how Turkey's entry into the Customs Union affects Turkey's foreign trade and how the Customs Union will affect Turkey's foreign trade in the future, was applied a questionnaire on the Likert scale. As a result
\end{abstract}


of variance test, there is no statistical significant difference between the education of the people and the expectation that the customs union will affect the exports and imports positively in the future.

Keywords: Custom Union, Foreign Trade, Perception, Variance Test

JEL Classification Codes: F15, F14, F13, F35

\section{GíRIŞ}

Sınırların kalktığı ve mal ve hizmet hareketliliğinin her geçen gün serbestleştiği dünyada ekonomik rekabet, uluslararası bir boyut kazanmış ve ülkeler açısından diş ticaret stratejik bir sektör haline gelmiştir. Ülkeler yeni pazarlara giriş ve ihracatlarını artırmak için dış ticaret sektörüne bir disiplin boyutunda yaklaşıp, bütün makroekonomik modellerini bu doğrultuda dizayn etmişlerdir. Yeni ekonomik dünyada ulusal iktisadi karar vericiler gücünü kaybedip, dış dünya diye tanımladığımız uluslararası karar vericiler güçlenmiş ve verdiği kararlar ile bütün ekonomiler olumlu ya da olumsuz etkilenir hale gelmiştir.

Dış ticaretin gelişme süreci, bir denge sorunu olarak karşımıza çıkmaktadır. Ekonomik varlığını sağlıklı bir biçimde sürdürmek isteyen ülkeler, ihracat-ithalat ilişkisini bir bilanço üzerinden takip ederek diş açıklarını yönetme eğilimindedirler. Şüphesiz bir ekonomide ihtiyaç olan bütün mal ve hizmetleri ülkelerin kendi imkânlarıyla üretmesi mümkün değildir. Bu durum diş dengede en optimum nokta olan, ihracat kadar ithalatı ülkeler için hedef haline getirmiştir. Ülkelerin bu hedefe ulaşmada karşılaştıkları en önemli sorun petrol ve doğalgaz gibi bazı enerji kaynaklarının dünyada çok az ülkede üretiliyor olmasına rağmen bütün ülkeler tarafından ara malı ve nihai mal olarak yüksek oranda kullanılıyor olmasıdır. Bu kısıttan dolayı ekonomi yönetimi mümkün olduğu kadar ithalatı azaltıcı, ihracatı artırıcı iktisat politikalarını tercih etmektedir.

Ekonomi yöneticileri ihracatı artırma ve ithalatı azaltma yolunda 4 temel dış ticaret politikasını tercih etmektedirler. Bunların başında döviz kuru politikaları gelmektedir. Döviz piyasasında devlet adına karar verici olan merkez bankası, döviz kuru politikasını belirlerken ihracatın ve ithalatın döviz kuruna olan esnekliğini hesaplayıp, en uygun döviz kuru politikasını tercih etmektedir. Ayrıca ekonomi yönetimleri istikralı bir dış ticareti süreci 
geliştirmek için teşvik (Ersungur,\&Yalman, 2009, s.81), AR-GE ve inovasyon politikalarından yararlanmaktadır. Fakat bugün dünyada ülkelerin en çok tercih ettikleri diş ticaret politikası iktisadi birleşme kaynaklı, dış ticaret politikalarıdır.

\section{1. İKTISADİ BİRLEŞME TEORILLERI}

Birden fazla ülkenin bir araya gelerek birbirleri ile yapacakları dış ticareti kendi aralarında yaptıkları bir sözleşmeye bağlı olarak gerçekleştirme sürecine uluslararası iktisadi birleşme denir. Bu sözleşmede ortak bir tarife uygulanırsa buna Gümrük Birliği denir (Hobikoğlu, 2007, s.76). Genelde komşu ülkelerle yapılan bir antlaşma türüdür(Businessdictionary,2017). Son yıllarda gümrük birliği tercihli ticaret antlaşmalarına rağmen artmaktadır(OECD, 2017). Bu süreç 5 temel aşamadan oluşmaktadır. Bu aşamaları içeren bir tablo aşağıda verilmiştir (Seyidoğlu, 1993, s.415-416).

Tablo 1. İktisadi Birleşme Türleri

\begin{tabular}{|c|c|}
\hline Tercihli Ticaret Antlaşması & $\begin{array}{l}\text { Dar kapsamlıdır. Birkaç ülke fayda } \\
\text { üzerine diș ticaret uygular. }\end{array}$ \\
\hline Serbest Ticaret Bölgesi & $\begin{array}{l}\text { Kendi aralarında gümrük tarifeleri ve } \\
\text { miktar kısıtlamaları kalkar. } \\
\text { Üçüncü ülkelere bağımsız dış ticaret } \\
\text { politikası uygulanır. }\end{array}$ \\
\hline Gümrük Birliği & $\begin{array}{l}\text { Kendi aralarında gümrük tarifeleri ve } \\
\text { miktar kısıtlamaları kalkar. Üçüncü } \\
\text { ülkelere ortak tarife politikası } \\
\text { uygulanır. }\end{array}$ \\
\hline Ortak Pazar & $\begin{array}{l}\text { Gümrük Birliğinin bütün özelliklerini } \\
\text { taşır. } \\
\text { Üretim faktörleri üye ülkeler arasında } \\
\text { serbestçe dolaşır. }\end{array}$ \\
\hline İktisadi Birlik & $\begin{array}{l}\text { Ortak Pazarın bütün özelliklerini taşır. } \\
\text { Ortak iktisat politikası uygulanır. }\end{array}$ \\
\hline
\end{tabular}

Kaynak: Yazar tarafindan türetilmiştir.

Daha çok birbirine yakın coğrafyada olan ya da komşu ülkeler arasında gerçekleşen (Şanl1, 2004, s.164.) bu iktisadi birleşmelerde amaç en az 
maliyetle ithalat yapıp en çok gelirle ihracatı gerçekleştirmektir. Türkiye'de 1 Ocak 1996 itibariyle Gümrük Birliği'ne tabi olmuştur (Uysal, 2001, s.146). Avrupa Birliğine tam üye olmadan gümrük birliğine giren ilk ülke Türkiye'dir (Uysal, 2001, s.147). Türkiye ile Avrupa Birliği arasında gerçekleşen Gümrük Birliği sanayi mallarını ve işlenmiş tarım ürünlerini kapsamaktadır (Avrupa Birliği Türkiye Delegasyonu, 2009).

Gümrük birliğine üye olmayan ülkelerden ithal edilecek bazı endüstri ürünleri için topluluk tarafından uygulanan ortak dış gümrük vergisine ilişkin uyumlaştırma 1 Ocak 2001 tarihinde tamamlanmıştır.

Otomobil, ayakkab1, deri ürünleri ve mobilya gibi ürünleri kapsayan bu gruba 'hassas malzemeler' denilmektedir (Avrupa Birliği Türkiye Delegasyonu, 2009). Bu sayede Türkiye, Avrupa Birliği ülkeleri ile arasındaki her türlü gümrük vergilerini kaldırmış, birliğe üye olmayan ülkelerle de Avrupa Birliği tarafından belirlenen ortak gümrük vergilerini uygulamaya başlamıştır. Türkiye'nin Avrupa birliğine üyeliği sürecindeki en kritik aşama şüphesiz Gümrük Birliğidir(Becker vd., 2016, s.41). Ayrıca Avrupa Birliği'nin de en kritik aşaması Gümrük Birliği'dir(Uyar, 2000, s.103)

\section{TÜRKIYYE'DE GÜMRÜK BİRLİĞI' NIIN DIŞ TICCARETE ETKİSI}

Türkiye'nin 1 Ocak 1996 itibariyle Gümrük Birliğine üye olduğunu yukarıda ifade etmiştik. 1997 yılı ile 2016 yılları arasındaki 25'li Avrupa birliği ülkeleri ile yapılan yıllık ihracat ve ithalat rakamlarının büyüme oranları ve iki büyüme oranı arasındaki farkı gösteren bir tablo aşağıda verilmiştir.

Tablo 2. 1997-2016 Yılları Arası İhracat-İthalat Değişim(25’li A.B.)

\begin{tabular}{|l|l|l|l|l|}
\hline Yıl & $\begin{array}{l}\text { Ülke Grup } \\
\text { Adı }\end{array}$ & $\begin{array}{l}\text { İhracat } \\
\text { Değişim }\end{array}$ & $\begin{array}{l}\text { İthalat } \\
\text { Değişim }\end{array}$ & $\begin{array}{l}\text { İhracat } \\
\text { İthalat }\end{array}$ \\
\hline $\mathbf{1 9 9 7}$ & 25'li A.B. & $7 \%$ & $8 \%$ & $-1 \%$ \\
\hline $\mathbf{1 9 9 8}$ & 25'li A.B. & $10 \%$ & $-3 \%$ & $12 \%$ \\
\hline $\mathbf{1 9 9 9}$ & $25 '$ li A.B. & $6 \%$ & $-11 \%$ & $17 \%$ \\
\hline $\mathbf{2 0 0 0}$ & 25'li A.B. & $1 \%$ & $25 \%$ & $-24 \%$ \\
\hline $\mathbf{2 0 0 1}$ & 25'li A.B. & $12 \%$ & $-31 \%$ & $43 \%$ \\
\hline $\mathbf{2 0 0 2}$ & $25 '$ li A.B. & $16 \%$ & $29 \%$ & $-14 \%$ \\
\hline $\mathbf{2 0 0 3}$ & 25'li A.B. & $33 \%$ & $37 \%$ & $-4 \%$ \\
\hline $\mathbf{2 0 0 4}$ & 25'li A.B. & $33 \%$ & $36 \%$ & $-3 \%$ \\
\hline $\mathbf{2 0 0 5}$ & 25'li A.B. & $11 \%$ & $8 \%$ & $3 \%$ \\
\hline
\end{tabular}




\begin{tabular}{|l|l|l|l|l|}
\hline $\mathbf{2 0 0 6}$ & 25'li A.B. & $15 \%$ & $12 \%$ & $3 \%$ \\
\hline $\mathbf{2 0 0 7}$ & 25'li A.B. & $24 \%$ & $15 \%$ & $9 \%$ \\
\hline $\mathbf{2 0 0 8}$ & 25'li A.B. & $5 \%$ & $9 \%$ & $-4 \%$ \\
\hline $\mathbf{2 0 0 9}$ & 25'li A.B. & $-24 \%$ & $-23 \%$ & $-1 \%$ \\
\hline $\mathbf{2 0 1 0}$ & 25'li A.B. & $12 \%$ & $26 \%$ & $-14 \%$ \\
\hline $\mathbf{2 0 1 1}$ & 25'li A.B. & $19 \%$ & $27 \%$ & $-8 \%$ \\
\hline $\mathbf{2 0 1 2}$ & 25'li A.B. & $-5 \%$ & $-4 \%$ & $-1 \%$ \\
\hline $\mathbf{2 0 1 3}$ & 25'li A.B. & $6 \%$ & $5 \%$ & $0 \%$ \\
\hline $\mathbf{2 0 1 4}$ & 25'li A.B. & $8 \%$ & $-4 \%$ & $13 \%$ \\
\hline $\mathbf{2 0 1 5}$ & 25'li A.B. & $-6 \%$ & $-11 \%$ & $4 \%$ \\
\hline $\mathbf{2 0 1 6}$ & 25'li A.B. & $6 \%$ & $-1 \%$ & $7 \%$ \\
\hline
\end{tabular}

Kaynak: Yazar tarafından Tuik Verilerinden Derlenmiştir.

Yukarıdaki Tablo 2, Gümrük Birliğinin Türkiye dış ticaretine katkısı konusunda bize kısmi bir analiz yapma şansı vermektedir. İhracattaki değişim incelendiğinde sadece 2009, 2012 ve 2015 y1llarında küçülme görülmüştür. Onun dışındaki yıllarda hep pozitif bir artış gözükmüştür. Fakat ithalat verileri incelendiğinde 1998, 1999, 2001, 2009, 2012, 2014, 2015, 2016 y1llarının tamamında azalma gözükmüştür. İhracat ile ithalat arasındaki büyüme farkı incelendiğinde, 1997, 2000, 2002, 2003, 2004, 2008, 2009, 2010, 2011, 2012 yıllarında bir önceki yıla göre ithalat oranındaki artış, bir önceki yıla göre ihracat oranındaki artıştan, fazla olmuştur.

Bir önceki yıla göre ihracat ve ithalattaki büyüme verilerini baz aldığımızda 1997 yılı ile 2016 yılları arası ihracattaki toplam büyüme \% 188, ithalattaki toplam büyüme ise \% 150'dir. Bu durumda bu dönemde hem ihracatta, hem ithalatta artış gözükmekle birlikte ihracattaki artış \% 38 oranında fazladır. Sonuç itibariyle kısmi bir analiz ile gümrük birliğinin Türkiye dış ticaretine hacimsel bir katkı sağladığı gözükmektedir.(Bayar ve Ozek1cioglu, 2011, s.16) Bu ticaret daha çok Almanya, İtalya, Fransa, İngiltere ve Hollanda ile olmuştur (Yucel, 2014, s.30).

Tablo 3. Gümrük Birliği- Türkiye Dış Ticaretine Etkisi Literatür Tablosu

\begin{tabular}{|c|c|c|c|}
\hline Yıl & Yazar & Yöntem & Sonuç \\
\hline
\end{tabular}




\begin{tabular}{|c|c|c|c|}
\hline 2006 & $\begin{array}{l}\text { Murat Doğanlar, } \\
\text { Harun Bal, } \\
\text { Mehmet Özmen, }\end{array}$ & $\begin{array}{l}\text { Engle-Granger ve } \\
\text { Johansen eş- } \\
\text { bütünleşme } \\
\text { yöntemleri }\end{array}$ & $\begin{array}{l}\text { İhracatın ve } \\
\text { İthalatın fiyat } \\
\text { esnekliklerinin } \\
\text { Gümrük Birliği } \\
\text { sonrasında } \\
\text { azaldığı sonucuna } \\
\text { ulaşmışlardır. }\end{array}$ \\
\hline 2006 & $\begin{array}{l}\text { Daniele } \\
\text { Antonucci, } \\
\text { Stefano } \\
\text { Manzocchi }\end{array}$ & $\begin{array}{l}\text { Yerçekimi(Gravitiy) } \\
\text { Modeli }\end{array}$ & $\begin{array}{l}\text { Gümrük Birliğinin } \\
\text { Türkiye-AB dış } \\
\text { ticaretine ilave } \\
\text { katkı sağladığına } \\
\text { dair kanıt } \\
\text { bulunamamıştır. }\end{array}$ \\
\hline 2007 & $\begin{array}{l}\text { Orhan Gündüz, } \\
\text { Kemal Esengün }\end{array}$ & $\begin{array}{l}\text { Chow Testi, Granger } \\
\text { Nedensellik Testi }\end{array}$ & $\begin{array}{l}\text { Gümrük } \\
\text { Birliği'nin ilk } \\
\text { y1llarında ithalatın } \\
\text { ihracattan daha } \\
\text { hızlı arttığı } \\
\text { saptanmıştır. }\end{array}$ \\
\hline 2007 & \begin{tabular}{|l} 
Levent \\
Kösekahyaoğlu
\end{tabular} & $\begin{array}{l}\text { Gini-Hirschman } \\
\text { Yoğunlaşma İndeksi }\end{array}$ & $\begin{array}{l}\text { Gümrük Birliğinin } \\
\text { sonucunda } \\
\text { ithalatın ürün } \\
\text { dağllımında } \\
\text { sadece küçük bir } \\
\text { değişim } \\
\text { yaşanırken, } \\
\text { ihracatın } \\
\text { yapısında çok } \\
\text { önemli değişikler } \\
\text { yaşanmıştır. }\end{array}$ \\
\hline 2007 & $\begin{array}{l}\text { Felıcitas Nowak } \\
\text { Lehmann, Dierk } \\
\text { Herzer, } \\
\text { Inmaculada } \\
\text { Martınez } \\
\text { Zarzoso }\end{array}$ & Panel Veri Analizi & $\begin{array}{l}\text { Gümrük Birliği } \\
\text { Sonrasında Tarım } \\
\text { Sektörü } \\
\text { İhracatında Gözle } \\
\text { Görülür bir artış } \\
\text { gözükmüştür. } \\
\text { Sanayi mallarında } \\
\text { ise hafif bir } \\
\text { ihracat artışı } \\
\text { olmuştur. }\end{array}$ \\
\hline
\end{tabular}




\begin{tabular}{|c|c|c|c|}
\hline 2007 & Emine Bilgili & $\begin{array}{l}3 \text { yıllık hareketli } \\
\text { ortalamalar } \\
\text { yardımıyla } \\
\text { karşılaştırmalı analiz }\end{array}$ & $\begin{array}{l}\text { Türkiye'nin } \\
\text { ihracat yapısında } \\
\text { önemli bir } \\
\text { değişme } \\
\text { gözlenmemiştir. }\end{array}$ \\
\hline 2007 & $\begin{array}{l}\text { Ertuğrul } \\
\text { Yıldırım } \\
\text { Cihan Dura }\end{array}$ & Literatür Taraması & $\begin{array}{l}\text { Türkiye'nin } \\
\text { aleyhine olan } \\
\text { ticaret yaratma } \\
\text { etkisi olmuştur. }\end{array}$ \\
\hline 2008 & $\begin{array}{l}\text { Alaattin Kiziltan, } \\
\text { Mustafa } \\
\text { Ersungur, Özgür } \\
\text { Polat }\end{array}$ & $\begin{array}{l}\text { Gölge Değişkenli } \\
\text { Ekonometrik } \\
\text { Modeller }\end{array}$ & $\begin{array}{l}\text { Gümrük Birliğinin } \\
\text { Türkiye Dış } \\
\text { Ticaretini Artırıcı } \\
\text { etki yaptığı } \\
\text { sonucuna } \\
\text { ulaşılmıştır. }\end{array}$ \\
\hline 2008 & $\begin{array}{l}\text { Antonis Adam, } \\
\text { Thomas Moutos }\end{array}$ & Panel Veri Analizi & $\begin{array}{l}\text { Türkiye Gümrük } \\
\text { Birliği ilişkisinde } \\
\text { AB-15 ülkeleri } \\
\text { arasındaki ticaret } \\
\text { üzerinde asimetrik } \\
\text { etkileri olduğunu } \\
\text { gösteren kanıt } \\
\text { sağlanmıştır. }\end{array}$ \\
\hline 2009 & Dilek Seymen & $\begin{array}{l}\text { Bilateral Yoğunlaşma } \\
\text { endeksi }\end{array}$ & $\begin{array}{l}\text { Gümrük } \\
\text { Birliği’nin } \\
\text { Türkiye ile AB } \\
\text { arasındaki } \\
\text { ticarette ülke } \\
\text { kompozisyonu } \\
\text { etkilerinin zayıf } \\
\text { kaldığı sonucuna } \\
\text { ulaşılmıştır. }\end{array}$ \\
\hline 2009 & Oğuzhan Türker & $\begin{array}{l}\text { Açıklanmış } \\
\text { Karşılaştırmalı } \\
\text { Üstünlükler }\end{array}$ & $\begin{array}{l}\text { Gümrük Birliğinin } \\
\text { Türkiye'nin } \\
\text { Rekabet Gücüne } \\
\text { önemli bir katkı } \\
\text { sağlamadığı } \\
\text { sonucuna } \\
\text { ulaşılmıştır. }\end{array}$ \\
\hline
\end{tabular}




\begin{tabular}{|c|c|c|c|}
\hline 2009 & $\begin{array}{l}\text { Cemalettin } \\
\text { Kalaycı } \\
\text { Seyfettin Artan }\end{array}$ & $\begin{array}{l}\text { Panel Veri Analizi, } \\
\text { Tesadüfi Etkiler } \\
\text { Modeli }\end{array}$ & $\begin{array}{l}\text { Türkiye’nin } 15 \text { ‘li } \\
\text { AB ile ihracatı } \\
\text { önemli ölçüde } \\
\text { artmıştır. }\end{array}$ \\
\hline 2010 & Ela Çolpan Nart & $\begin{array}{l}\text { Panel Veri Analizi, } \\
\text { Wald Testi }\end{array}$ & $\begin{array}{l}\text { Dış Ticaret Hacmi } \\
\text { artmış ve İhracat, } \\
\text { İthalattan daha } \\
\text { hızlı artmıştır. }\end{array}$ \\
\hline 2010 & $\begin{array}{l}\text { Antalya AB } \\
\text { Bilgi Merkezi }\end{array}$ & Oran Analizi & $\begin{array}{l}\text { Gümrük } \\
\text { Birliği'nin } \\
\text { Türkiye'nin } \\
\text { zararına bir durum } \\
\text { teşkil etmediği } \\
\text { hatta faydasına } \\
\text { sonuçlar } \\
\text { oluşturduğu } \\
\text { söylenebilir. }\end{array}$ \\
\hline 2011 & $\begin{array}{l}\text { Seyhun Doğan, } \\
\text { Sema Nur } \\
\text { Soyyiğit Kaya }\end{array}$ & $\begin{array}{l}\text { Yoğunlaşma Oranı, } \\
\text { Herfindahl İndeksi }\end{array}$ & $\begin{array}{l}\text { Gümrük Birliği } \\
\text { Türkiye Dış } \\
\text { Ticaretini Pay } \\
\text { olarak } \\
\text { etkilemezken } \\
\text { kompozisyon } \\
\text { olarak } \\
\text { etkilemiştir. }\end{array}$ \\
\hline 2012 & $\begin{array}{l}\text { Bilin Neyaptı, } \\
\text { Fatma Taşkın ve } \\
\text { Murat Üngör }\end{array}$ & $\begin{array}{l}\text { Zaman Serileri } \\
\text { Analizi, F Testi ve } \\
\text { Hausman Testi, Sabit } \\
\text { Etkenler Modeli }\end{array}$ & $\begin{array}{l}\text { Gümrük Birliği } \\
\text { sonrasında reel } \\
\text { kur politikası } \\
\text { ticaret } \\
\text { performansını } \\
\text { artırmıştır. }\end{array}$ \\
\hline 2013 & $\begin{array}{l}\text { Melih Özçalık, } \\
\text { Ahmet Okur }\end{array}$ & $\begin{array}{l}\text { Açıklanmış } \\
\text { Karşılaştırmalı } \\
\text { Üstünlükler }\end{array}$ & $\begin{array}{l}\text { AB } 15 \text { ülke } \\
\text { temelinde tekstil } \\
\text { ve Hazır Giyim } \\
\text { sektöründe dış } \\
\text { ticaret kazancı } \\
\text { elde etmediği } \\
\text { sonucuna } \\
\text { ulaşılmıştır. }\end{array}$ \\
\hline
\end{tabular}




\section{GÜMRÜK BİRLİĞININ DIŞ TİCARETE ETKİSi ÜZERİNE BİR ALGI ARAŞTIRMASI}

Çalışmanın bu kısmında, Türkiye'nin Gümrük Birliği'ne girmesinin, Türkiye dış ticaretine etkisi ve Gümrük Birliği'nin gelecekte Türkiye dış ticaretinin nasıl etkileyeceği konularında kişilerin düşüncelerini almak amacıyla likert ölçekte bir anket uygulaması yapılmıştır. Ankete toplam 483 kişi cevap vermiştir. Anket Türkiye'de İstanbul, Ankara, Antalya, Burdur, Isparta, Denizli, Konya ve Şanlıurfa illerinde uygulanmıştır. Ankete cevap verenlerin \%90'1 18-45 yaş aralığında olup gümrük birliğinin etkilerini analiz edebilecek yaşam deneyimine sahip kişilerdir. Ayrıca anketimize cevap verenlerin eğitim durumu incelendiğinde $\% 82$ 'si önlisans ve üzeri eğitim seviyesine sahiptir. Anketimize cevap verenlerin mesleki dağılımı incelendiğinde \% 52'si kendi işyeri sahibi kişilerden oluşmaktadır.

Uygulanan anketin güvenilirlik testinde Cronbach's Alpha değeri 0,71 çıkmıştır. Güvenilirlik testi ile ilgili literatür incelendiğinde(Tavakol\& Dennick, 2011, s.54) bu değer ölçeğimizin güvenilir olduğunu göstermektedir (Kalayc1, 2005, s. 405).

Tablo 4. Anket Sonuçlarının Temel İstatistik Sonuçları

\begin{tabular}{|l|l|l|l|l|l|}
\hline & N & Ortalama & $\begin{array}{l}\text { Standart } \\
\text { Sapma }\end{array}$ & Skewness & Kurtosis \\
\hline $\begin{array}{l}\text { Türkiye'nin } \\
\text { Gümrük } \\
\text { Birliği'ne girmesi } \\
\text { ihracatın } \\
\text { artmasında etkili } \\
\text { olmuştur. }\end{array}$ & 483 & 3.4741 & 1,1544 &,- 875 & $-0,131$ \\
\hline $\begin{array}{l}\text { Türkiye'nin } \\
\text { Gümrük } \\
\begin{array}{l}\text { Birliği'ne girmesi } \\
\text { ithalatın } \\
\text { artmasında etkili } \\
\text { olmuştur. }\end{array}\end{array} \quad 483$ & 3,7826 & 0,9707 & $-1,125$ & 1,187 \\
\hline
\end{tabular}




\begin{tabular}{|c|c|c|c|c|c|}
\hline $\begin{array}{l}\text { Türkiye'nin } \\
\text { Gümrük } \\
\text { Birliği’ne } \\
\text { girmesinin } \\
\text { üçüncü ülkelerle } \\
\text { yapılan Dış } \\
\text { Ticaret'i olumlu } \\
\text { etkilediğini } \\
\text { düşünüyorum. }\end{array}$ & 483 & 3,3913 & 1,0575 &,- 547 &,- 350 \\
\hline $\begin{array}{l}\text { Türkiye'nin } \\
\text { Gümrük } \\
\text { Birliği'ne } \\
\text { girmesinin } \\
\text { Türkiye'de Ar-Ge } \\
\text { yatırımını } \\
\text { arttırdığını } \\
\text { düşünüyorum. }\end{array}$ & 483 & 3,4617 & 1,0124 &,- 624 &,- 137 \\
\hline $\begin{array}{l}\text { Gümrük } \\
\text { birliğinin } \\
\text { gelecekte ihracatı } \\
\text { arttıracağını } \\
\text { düşünüyorum. }\end{array}$ & 483 & 3,4513 & 1,1319 &,- 659 &,- 407 \\
\hline $\begin{array}{l}\text { Gümrük } \\
\text { birliğinin } \\
\text { gelecekte ithalatı } \\
\text { arttıracağını } \\
\text { düşünüyorum. }\end{array}$ & 483 & 3,6620 & 1,0200 &,- 781 & ,131 \\
\hline $\begin{array}{l}\text { Türkiye'nin } \\
\text { Gümrük } \\
\text { Birliğinden } \\
\text { çıkması } \\
\text { gerektiğini } \\
\text { düşünüyorum. }\end{array}$ & 483 & 2,4037 & 1,1178 & ,614 &,- 206 \\
\hline $\begin{array}{l}\text { Türkiye'nin } \\
\text { Gümrük } \\
\text { Birliği’ne } \\
\text { girmesiyle bazı } \\
\text { lüks malların } \\
\text { fiyatlarının }\end{array}$ & 483 & 2,9979 & 1,1886 &,- 085 & $-1,015$ \\
\hline
\end{tabular}




\begin{tabular}{|l|l|l|l|l|l|}
\hline $\begin{array}{l}\text { ucuzladığını } \\
\text { düşünüyorum. }\end{array}$ & & & & & \\
\hline Gümrük & 483 & 2,9752 & 1,2421 &,- 122 & $-1,062$ \\
Birliği'nin & & & & & \\
Türkiye'de yerli & & & & & \\
üretimi & & & & & \\
geliş̧tirdiğini ve & & & & & \\
arttırdığını & & & & & \\
düşünüyorum. & & & & & \\
\hline
\end{tabular}

Tablo 4'de anket sorularımıza verilen cevapların temel istatistik değerleri verilmiştir. Anketimizde 5'li likert ölçek kullanılmıştır. 1 cevabının kesinlikle katılmıyorum olduğu, 5 cevabının ise kesinlikle katılıyorum olduğu ölçeğimizde ortanca değer 3'tür. Dolayısıyla yukarıdaki ortalama değerler incelendiğinde anketimize cevap verenlerin büyük kısmının gümrük birliğinin bugün ve gelecekte Türkiye ihracat ve ithalatını artırdığı düşüncesine sahiptirler.

Ayrıca anketimize cevap verenlerin gümrük birliğinin, ülkemizde lüks malların fiyatlarını düşürmediği ve yerli üretimi de olumu etkilemediği algısına sahip olduklarını söyleyebiliriz. Son olarak anketimize cevap verenlerin Türkiye'nin gümrük birliğinden çıkmaması gerektiği düşüncesine sahip olduklarını söyleyebiliriz.

Tablo: 4 incelendiğinde bütün değişkenlerimiz için Skewness ve Kurtosis değerlerinin -1 ile +1 arasında değiştiği gözükmektedir. Bu aralığın, normal dağılım için sıkıntısız bir aralık olduğu genel kabul görmektedir (Morgan, Leech, Gloeckner, Barret, 2004, s. 59 ). Ayrıca standart sapma değerlerimizin birbirine çok yakın oldukları gözükmektedir.

Temel İstatistikler incelendikten sonra anketimize cevap verenlerin kuşak aralığı ile eğitim durumlarının farklılaştığı durumlarda verdikleri cevaplarda istatistiksel olarak anlamlı bir farklılığın varlığı test edilecektir. ANOVA testi iki ya da ikiden fazla bağımsız değişken arasında ortalamaların istatistiksel olarak anlamlı bir farklılığa sahip olup olmadığını gösterir. Bu testin iki temel varsayımı vardır. Varsayımlardan birisi, bağımsız 
değişkenlerin normal dağılması gerekmektedir. $\mathrm{Bu}$ durum yukarıda bahsedilmiştir. Temel hipotezlerimiz aşağıdaki gibidir.

$\mathrm{HO}(1)=$ Kişilerin eğitim durumu ile gümrük birliğinin gelecekte ihracatı olumlu etkileyeceği beklentisi arasında istatistiksel olarak anlamlı bir farl111k yoktur.

$\mathrm{H} 0(2)=$ Kişilerin eğitim durumu ile gümrük birliğinin gelecekte ithalatı olumlu etkileyeceği beklentisi arasında istatistiksel olarak anlamlı bir farlıl1k yoktur.

H0(3) = Kişilerin yaş aralığı ile gümrük birliğinin gelecekte ihracatı olumlu etkileyeceği beklentisi arasında istatistiksel olarak anlamlı bir farlılık yoktur.

$\mathrm{H} 0(4)=$ Kişilerin yaş aralığı ile gümrük birliğinin gelecekte ithalatı olumlu etkileyeceği beklentisi arasında istatistiksel olarak anlamlı bir farlılık yoktur.

ANOVA testinin bir diğer varsayımı, etkilenen değişkene ilişkin varyansların homojen olması gerekmektedir (Büyüköztürk, 2007, s.47). Çalışmada varyansların homojenliği testi için Levene istatistiği kullanılmıştır. Levene istatistiğinde grupların eşit varyanslara sahip olduğu yönündeki temel hipotez 0.05 anlamlılık seviyesinde olasılık değerleri yardımıla incelenir.

Tablo 5. Varyansların Homojenliği Test Sonuçları

\begin{tabular}{|l|c|c|}
\hline & Levene İstatistiği & Olasılık Değeri (Sig) \\
\hline $\begin{array}{l}\text { Ĕgitim-İhracat } \\
\text { Beklentisi }\end{array}$ & 1,639 & 0,179 \\
\hline $\begin{array}{l}\text { Ĕgitim- İthalat } \\
\text { Beklentisi }\end{array}$ & 1,859 & 0,136 \\
\hline $\begin{array}{l}\text { Yaş Aralığı -İhracat } \\
\text { Beklentisi }\end{array}$ & 0,381 & 0,822 \\
\hline $\begin{array}{l}\text { Yaş Aralığı-İthalat } \\
\text { Beklentisi }\end{array}$ & 0,676 & 0,609 \\
\hline
\end{tabular}

Bu tabloya göre kişilerin eğitim durumu ile yaş aralığının faktör olduğu geleceğe ilişkin ihracat ve ithalat beklentisinin bağımlı değişken olduğu 
analizimizde 0,05 anlamlılık düzeyinde varyanslar homojen dağılmıştır (Kalayc1, 2005, s. 219).

Tablo. 6 ANOVA Test Sonuçları

\begin{tabular}{|l|c|c|r|c|}
\hline $\begin{array}{l}\text { Gruplar } \\
\text { Arası }\end{array}$ & $\begin{array}{c}\text { F } \\
\text { Değeri }\end{array}$ & $\begin{array}{r}\text { Olasılık } \\
\text { Değeri(sig) }\end{array}$ & $\begin{array}{r}\text { Kareler } \\
\text { Toplamı }\end{array}$ & $\begin{array}{r}\text { Kareler } \\
\text { Ortalaması }\end{array}$ \\
\hline $\begin{array}{l}\text { Ĕ̆itim- } \\
\text { İhracat } \\
\text { Beklentisi }\end{array}$ & 0,303 & 0,876 & 1,560 & 0,390 \\
\hline $\begin{array}{l}\text { Ĕgitim- } \\
\text { İthalat } \\
\text { Beklentisi }\end{array}$ & 1,933 & 0,104 & 7,998 & 1,991 \\
\hline $\begin{array}{l}\text { Yaş } \\
\text { Aralı̆̆ı - } \\
\text { İhracat } \\
\text { Beklentisi }\end{array}$ & 2,656 & 0,032 & & \\
\hline $\begin{array}{l}\text { Yaş } \\
\text { Aralı̆̆ı- } \\
\text { İthalat } \\
\text { Beklentisi }\end{array}$ & & & & \\
\hline
\end{tabular}

Yukarıdaki Tablo:6.' de 4 hipotezimiz için (H0(1), H0(2), H0(3),H0(4)) ANOVA test sonuçları verilmiştir. Tablo:6 incelendiğinde, $\mathrm{HO}(3)$ haricindeki bütün hipotezler için olasılık değeri 0.05 'den büyük çıktığı için hipotezler kabul edilmektedir. Kişilerin aldığı eğitim ile gelecekte gümrük birliğinin ihracatı ve ithalatı olumlu etkileyeceği beklentisi arasında istatistiksel bir fark bulunamamıştır. Her eğitim seviyesinde kişiler gümrük birliğinin dış ticarete gelecekte olumlu katkı sağlayacağına inanmaktadır. Fakat kişilerin yaş aralığı ile gümrük birliğinin gelecekte ihracatı olumlu etkileyeceği beklentisi arasında istatistiksel bir farklılık çıkmıştır. Bunun sebebini iki nedene bağlamak mümkündür.

Birincisi ankete cevap verenlerin yaş aralıkları büyük çoğunluğunun 35 yaş aralığının altında olmasıdır. Anketimize cevap verenlerin sadece \%12'si 46 yaşın üzerindedir. Genç nüfusta bir yoğunlaşma olması istatistiksel anlamlılık ortaya çıkarmaktadır. İkinci neden ise anketimize cevap verenlerin 95 
çoğunluğu gümrük birliğinin yerli üretimi geliştirmediğini düşünmektedir. $\mathrm{Bu}$ durumda istatistiksel bir fark oluşturmuş olabilir.

\section{SONUÇ}

Varlığını istikrarlı bir biçimde sürdürmek isteyen Türkiye ekonomisinin ithalat kadar ihracat hedefi bulunmaktadır. Bu hedefe ulaşmada en çok konuşulacak konuların başında Gümrük birliğine üyelik süreci gelmektedir. Ülkemizde Gümrük birliğinin Türkiye ekonomisi üzerine etkileri birçok araştırmacı tarafindan çalışılmış olup, analizler göstermektedir ki mutlak anlamda olumlu ya da olumsuz yargılar üretmek zor gözükmektedir. Çalışmalar incelendiğinde gümrük birliğinin dış ticaret hacmini artırdığı net bir şekilde ifade edilirken, üye olunmaması durumunda ya da alternatif bir toplulukla gümrük birliği yapılması sonucunda dış ticaret gelişimini, akademik bir yaklaşımla analiz etmek imkânsızdır. Türkiye'nin 1996 yılı ile 2017 yılları arası dış ticaret trendi incelendiğinde bu bölge ile de diğer bölgelerle de yapılan ihracat ve ithalat faaliyetlerinde artış olmuştur.

Bu çalışmada 1997-2016 yıllar arası 25'li Avrupa Birliği ülkeleriyle yapılan ihracat ve ithalat verileri incelenmiş olup, ihracattaki bir önceki yıla göre toplam artış \% 188, ithalattaki bir önceki yıla göre toplam artış ise \% 150 gerçekleşmiştir. İhracatta ki artış \% 38 oranında fazladır. Sonuç itibariyle kısmi bir analiz ile gümrük birliğinin Türkiye dış ticaretine olumlu katkı sağladığı söylenebilir.

Çalışmanın son bölümünde kişilerin, gümrük birliğinin Türkiye dış ticaretine etkisi konusundaki düşünceleri bir anket yardımıyla ölçülmeye çalışılmıştır. Anket sonuçları kişilerin eğitim durumu ve yaş aralığından farkl11ı göstermeksizin Gümrük birliğinin ihracata ve ithalata olumu etki sağladığı düşüncesine sahip olduklarını göstermektedir. Ayrıca anketimize cevap veren kişilerin Türkiye'nin gümrük birliğinden çıkmaması gerektiği fikrine sahip olduklarını söylenebilir.

\section{KAYNAKLAR}

Adam, A. \& Moutos, T., (2008). The Trade Effects of the EU-Turkey Customs Union. The World Economy, 31(5), 685-700. 
Antalya AB Bilgi Merkezi (2010), Gümrük Birliği'nin Türk Ekonomisine Etkileri. https,//www.atso.org.tr/icerik/3/77/antalya-ab-bilgi-merkezi.html, erişim tarihi, 24.03.2017

Antonucci, D. \& Manzocchi, S. (2006). Does Turkey have a special trade relation with the EU?. A gravity model approach, Elsevier, Economic System. 30(2), 157-169.

Bayar, I. \& Ozekıcıoğlu, Y. (2011). Effects Of European Unıon-Turkey Customs Unıon On Turkısh Foreıgn Trade, Studies in Business and Economics, ccsf.ulbsibiu.ro/articole/vol92/922bayar\&ozekicioglu.pdf, Erişim Tarihi,06.02.2017, adresinden alındı.

Becker, K., Baki, I., \& Lee, J.W. (2016). The Customs Union between the European Union and Turkey and its Impacts on Turkey's Economy, Journal of Asian Finance, Economics and Business, 3(2), 41-49.

Bilgili, E. (2007). Gümrük Birliği Sonrası Türkiye'nin Batı Avrupa'ya Olan İhracatının Sektörel Analizi. Ege Akademik Bakış Dergisi, 7(1) , 239250.

Büyüköztürk, Ş. (2007). Sosyal Bilimler için Veri Analizi El Kitabı. 7. Bask1, Ankara: Pegem Yayıncılik.

Doğan, S. \& Kaya Soyyiğit, S.(2011), Gümrük Birliği Sonrasında (19962009) Türkiye'nin Avrupa Birliği İle Dış Ticaretinin Ülke Ve Fasıl Bazlı Yoğunlaşma Analizi. Ekonometri ve İstatistik e-Dergisi, 14, 1-18.

Doğanlar, M., Bal, H., \& Özmen, M. (2006)., Türkiye ile Almanya arasındaki dış ticaretin ekonometrik analizi ve gümrük birliği sonrası karşılaştırma. İktisat İşletme ve Finans Dergisi, 21, 50-65

Ersungur, M. \& Yalman, İ.N. (2009). Bölgesel Kalkınmada İhracat Teşviklerinin Etkinliği, Sivas İlinde Bir Uygulama. Cumhuriyet Üniversitesi Íktisadi ve İdari Bilimler Dergisi, 10(1), .81-98

Gündüz, G. \& Esengün K. (2007). Gümrük Birliğinin Türkiye'nin Avrupa Birliği (15) İle Dış Ticareti Üzerine Etkileri. Ziraat Fakültesi Dergisi, 24 (1), 43-49.

Hatipler, M. (2012). Türkiye- Ab Gümrük Birliği Antlaşması Ve Antlaşmanın Türkiye Ekonomisine Etkileri. Akademik Bakış Dergisi, 29, 1-14.

Hobikoğlu, E.H. (2007). Gümrük Birliklerinin Ekonomik Etkileri ve Türkiye Ekonomisi, Gümrük Birliği Yansımaları. Sosyal Bilimler Dergisi, 1, 65-82.

http,//avrupa.info.tr/tr/abde-ticaret-ve-ekonomi/guemruek-birligi.html, erişim tarihi, 1.02.2017, adresinden alınd1.

http://www.businessdictionary.com/definition/customs-union.html, erişim tarihi: 03.07.2017, adresinden alınd.

https://stats.oecd.org/glossary/detail.asp?ID=3130, erişim tarihi: 03.07.2017, adresinden alınd1. 
Kalayc1, C. \& Artan, S. (2009). Gümrük Birliğinin Türkiye'nin D1ş

Ticaretine Etkileri, Panel Veri Analizi.

https,//birimler.dpu.edu.tr/app/views/panel/ckfinder/userfiles/17/.../30

1-314.pdf, erișim tarihi, 24.03.2017. 1-11, adresinden alındı.

Kalayc1, Ş. (2005). SPSS Uygulamalı Çok Değişkenli İstatistik Teknikleri, Ankara: Asil Yayın Dağıtım

Kızıltan, A., Ersungur, M., \& Polat, Ö. (2008). Gümrük Birliğinin Türkiye'nin Avrupa Birliği İle İhracat Ve İthalatına Etkisi. Atatürk Üniversitesi İktisadi ve İdari Bilimler Fakültesi, 22(1), 83-99.

Kösekahyaoğlu, L. (2007). Türkiye Dış Ticaretinde Ürün ve Ülke Bazında Yoğunlaşma, 1980-2005 Dönemi Üzerine Karşılaştırmalı Bir Analiz, I.Ü. Siyasal Bilgiler Fakültesi Dergisi, 36, 15-34.

Morgan, B., George, A., Nancy. L.L., Gloeckener, G.W. \& Karen. C. B. (2004). SPSS for Introductor,.Statistics, Use and Interpretation. Second Edition. London: Lawrance Erlbaum Associates.

Nart, E. Ç. (2010). Gümrük Birliği'nin Türkiye'nin D1ş Ticareti Üzerine Etkileri Panel Veri Analizi. Journal of Yasar University, 17(5), 28742885 .

Neyaptı, B., Taşkın, F., \& Üngör, M. (2012). Gümrük Birliği'nin Türkiye'nin Bölgesel Ticaretine Etkileri. Türkiye Ekonomi Kurumu Tartışma Metni, 1-10. http ,//www.Tek.Org.Tr

Nowak F., Herzer, D., \& Zarzoso, I. (2007). The Impact of a Customs Union between Turkey and the EU on Turkey's Exports to the EU. Journal of Common Markets Studies, 45(3), 719-743.

Özçalık, M. \& Okur, A. (2013). Türk tekstil ve hazır giyim sektörlerinin gümrük birliği sonrası $\mathrm{AB}-15$ ülkeleri karşısındaki rekabet gücü, $C B \ddot{U}$ Sosyal Bilimler Dergisi, 11(1), 205-223.

Seyidoğlu, H. (1993). Uluslararası İktisat, İstanbul: Güzem Yayınları, 415416

Seymen, D. (2009). Gümrük Birliği, Türkiye'nin Avrupa Birliği İle Ticaretinde Ülke Yoğunlaşmasını Değiştirdi mi?, Süleyman Demirel Üniversitesi Iktisadi ve İdari Bilimler Fakültesi Dergisi, 14(1), 199-220

Şanlı, B. F. (2004). Küreselleşme Ve Ekonomik Entegrasyonlar. Doğu Bölgesi Araştırmaları, 160-166

Tavakol, M. \& Dennick, R. (2011). Making sense of Cronbach's alpha. International Journal of Medical Education, 2, 53-55.

Türker, O. (2009). Gümrük Birliği Sonras1 Türkiye'nin Dış Ticaretinin Rekabet Gücü, Erciyes Üniversitesi İktisadi ve İdari Bilimler Fakültesi Dergisi. 32, 281-302.

Uyar, S. (2000), Ekonomik Bütünleşmeler ve Gümrük Birliği Teorisi. Dış Ticaret Dergisi, 19, 103-130. 
Uysal, U. (2001). Türkiye -Avrupa Birliği İlişkilerinin Tarihsel Süreci ve Son Gelişmeler. Akdeniz I.I. B.F. Dergisi, 1, 140-153

Yıldırım, E. \& Dura, C. (2007). Gümrük Birliği'nin Türkiye Ekonomisi Üzerindeki Etkileri Konusundaki Literatüre Bir Bakış. Erciyes Üniversitesi Iktisadi Ve İdari Bilimler Fakültesi Dergisi, 28, 141-177

Yucel, E.Y. (2014). The Effects of EU Customs Union Integration on Turkish Intra-Industry Trade. Emerging Markets Journal, 4(1), 16-32. 